\title{
Augmented Reality Pengenalan Landmark Negara Asia Tenggara Menggunakan Algoritma FAST Corner Dan Natural Feature Tracking
}

\author{
Adam Raihan Fadhlurrahman ${ }^{1}$, auziah $^{2}$, Aris Gunaryati ${ }^{3}$ \\ ${ }^{1,2,3}$ Informatika, Fakultas Teknologi Komunikasi dan Informatika Universitas Nasional \\ Jl. Sawo Manila, Pejaten Ps. Minggu Jakarta 12520 \\ e-mail: ${ }^{1}$ adamrf046@gmail.com, ${ }^{2}$ fauziah@ @ivitas.unas.ac.id, ${ }^{3}$ aris.gunaryati@civitas.unas.ac.id
}

\begin{abstract}
Abstrak
Pada saat ini diseluruh bagian dunia sedang terlanda sebuah virus yaitu COVID-19 yang membuat setiap orang tidak dapat berpergian ke luar negri dengan mudah. Namun di era sudah canggih ini semua informasi dapat disajikan secara digitalisasi mulai dalam bentuk tulisan maupun gambar dan dapat juga ditampilkan berbentuk objek 3 dimensi dibantu dengan Augmented Reality untuk menampilkannya. Peneleitian ini memanfaatkan teknologi Augmented Reality digunakan untuk alat pengenalan landmark dari negara Asia Tenggara agar tampilan objek akan menjadi lebih atraktif dan dapat mengetahui informasi tentang landmark dari setiap negara dengan mudah. Dalam penelitian ini aplikasi Augmented Reality dibuat menggunakan FAST Corner Detection (FCD) algoritma dan Natural Feature Tracking (NFT) untuk mendeteksi marker. Pengujian dari aplikasi ini dilakukan pada tiga perangkat smartphone android, pada sudut kemiringan $20^{\circ}$ - $90^{\circ}$ ketiga smartpone dapat mendeteksi marker menggunakan kameranya dan menampilkan objek 3 dimensi sesuai dengan landmark yang dipilih pada layar smartphone. Untuk pengukuran jarak maximal yang dapat dibaca oleh handphone rata-rata $\pm 75 \mathrm{~cm}$ dan jarak minimun pendeteksian yaitu $\pm 10 \mathrm{~cm}$.
\end{abstract}

Kata kunci-Augmented Reality, Landmark, FCD, NFT.

\begin{abstract}
At the moment, all parts of the world are being hit by a virus called COVID-19 which makes it not easy for everyone to travel abroad. But in this sophisticated era all information can be presented digitally starting in the form of writing and images and can also be displayed in the form of 3-dimensional objects assisted by Augmented Reality to display it. This research utilizes Augmented Reality technology used for landmark recognition tools from Southeast Asian countries so that the appearance of objects will be more attractive and can know information about landmarks from each country easily. In this study Augmented Reality applications were created using FAST Corner Detection (FCD) algorithms and Natural Feature Tracking (NFT) to detect markers. Testing of this application is done on three android smartphone devices, at a tilt angle of $20^{\circ}-90^{\circ}$ the third smartpone can detect markers using its camera and display 3-dimensional objects according to the selected landmarks on the smartphone screen. For maximal distance measurement that can be read by mobile phone average $\pm 75 \mathrm{~cm}$ and minimum detection distance is $\pm 10 \mathrm{~cm}$.
\end{abstract}

Keywords - Augmented Reality, Landmark, FCD, NFT. 


\section{PENDAHULUAN}

$\mathrm{L}$ andmark ialah elemen yang penting dari sebuah kota atau daerah, landmark mempunyai tugas berarti untuk menolong seseorang dalam memusatkan diri dari titik orientasi untuk memahami wilayah itu sendiri secara keseluruhan [1]. Landmark telah menjadi bangunan penting dari suatu wilayah, seringkali landmark ini mempunya informasi penting yang terkait didalamnya. Dengan kondisi global saat ini yang sedang dilanda virus COVID - 19, mengubah sistem pembelajaran yang semula onsite dimana siswa belajar di sekolah kali ini menjadi sistem online yang bersifat sementara untuk mencegah penyebaran virus COVID - 19 ini. Karena hal tersebut pembelajaran menjadi kurang baik. Hal ini juga mempengaruhi masyarakat umum yang tidak dapat berkunjung dan melihat langsung landmark untuk mengetahui bagaimana bentuk asli dari landmark tersebut. Kenampakan keadaan landmark dari negara - negara di asia tenggara biasanya hanya ditampilkan berbentuk gambar yang berada di dalam buku, yang dimana gambar tidak menampilkan keselurah bentuk dari landmark. Hal tersebutlah yang membuat setiap orang masih sangat sulit untuk membayangkan bentuk asli dari gambar yang terdapat pada buku. Dengan demikian teknologi Augmented Reality ini akan menjadi solusi alternative untuk membantu masyarakat umum dalam mempelajari landmark - landmark negara yang ada di Asia Tenggara dengan bentuk object 3D atraktif yang nantinya dapat terlihat dengan jelas bentuk dari landmark dari setiap negara yang disertai dengan informasi yang ada pada landmark negara tersebut [2].

Saat ini teknologi di dunia telah berkembang sangat cepat, dengan perkembangan teknologi ini banyak manfaat yang didapatkan untuk masyarakat umum khususnya dalam sektor pendidikan. Pemanfaatan teknologi ini dapat membantu manusia dalam berbagai hal seperti memberikan informasi dan sebagai media belajar, dalam hal ini teknologi telah menjadi sebuah kebutuhan penting bagi masyarakat. Teknologi yang tengah berkembang dengan pesat didunia yaitu Augmented Reality. Augmented Reality yaitu sebuah teknologi yang mampu memadukan lingkungan maya dan nyata secara real time dan di proyeksikan dalam bentuk objek 3D pada perangkat smartphone [3].

Pada penelitian yang sebelumnya dengan hal serupa menggunakan augmented reality pada aplikasi untuk menampilkan dan mengenalkan landmark asia tenggara pada anak sekolah dasar yang bertujuan agar meningkatkan minat belajar para siswa sekolah dasar [1]. Pada penelitian yang lain dengan augmented reality juga dimanfaatkan untuk pengenalan landmark yang ada di kota Surakarta dengan memiliki tujuan untuk dapat menampilkan informasi yang dapat mudah dimengerti oleh para wisatawan [4]. Penelitian yang mempunyai topik seragam dengan riset ini juga terdapat pada penelitian augmented reality yang memanfaatkan metode marker based tracking untuk landmark dari negara - negara ASEAN yang bertujuan untuk menampilkan objek 3D landmark sebagai media pembelajaran [5]. Peneleitin lainnya yang terkait juga dilakukan untuk mengenalkan objek wisata dari taman air yang berada di karang asem menggunakan vuforia engine dalam membantu menampilkan objek 3D dan bertujuan untuk membandingkan gambar asli dari bangunan dengan objek 3D yang ditampilkan dan menampilkan informasi terkait bangunan [6].

Penelitian ini bertujuan untuk menciptakan suatu aplikasi pengenalan landmark negara asia tenggara untuk masyarakat menggunakan teknologi Augmented Reality dengan FCD serta menggunakan NFT. Dengan menggunakan aplikasi pengenalan akan membantu anak-anak mempelajari landmark negara asia tenggara dengan cara yang menyenangkan.

Adam, et.,al, [Augmented Reality Pengenalan Landmark Negara Asia Tenggara Menggunakan Algoritma FAST Corner Dan Natural Feature Tracking] 


\section{METODE PENELITIAN}

\subsection{Augmented Reality}

Augmented reality yaitu suatu teknologi multimedia dimana dapat membantu manusia dalam memvisualisasikan objek maya 2D ataupun 3D ke lingkungan sebenarnya dalam waktu yang nyata [7]. Teknologi augmented reality sendiri merupakan teknologi yang sering digunakan belakangan ini untuk penyampaian informasi. Penggunaan teknologi ini sangat membantu dalam penyampaiannya karena lebih interaktif.

\subsection{Unity $3 D$}

Unity adalah sebuah software gratis yang terhubung dengan perangkat yang digunakan dalam pembuatan aplikasi 3D dengan interaktif dan memiliki sifat multi platform. Unity dapat mempermudah pengembang dalam mewujudkan object, mengimport asset yang berasal dari luar dan menguhubungkan hal itu dengan cepat dan efisien [8]. Unity 3D juga mendukung berbagai platform dalam pembuatan aplikasi, aplikasi yang dibuat dari menggunakan Unity 3D bisa digunakan di banyak perangkat seperti personal computer, smartphone Android, IOS, XBOX, PlayStation.

\subsection{Vuforia}

Vuforia merupakan Augmented Reality SDK berbasis perangkat mobile dimana membantu dalam pembuatan aplikasi Augmented Reality [9]. SDK vuforia dapat menguhubungkan ke unity dengan bantuan yang diberikan berupa Vuforia AR Extension For Unity. Vuforia sendiri memanfaatkan layar smartphone untuk dapat melihat lingkungan Augmented Reality dimana lingkungan nyata dengan lingkungan virtual muncul berdampingan. SDK Vuforia menyediakan beberapa jenis target mulai dari 2D sampai 3D termasuk juga multi target serta target markerless.

\subsection{FAST Corner Detection}

FAST Corner Detection ialah sebuah algorithm dimana memiliki kerja melacak sudut dari objek yang dipakai. FCD sendiri memiliki tujuan meningkatkan tingkat ketepatan akurasi deteksi sudut dengan cara real-time [10]. Algoritma FCD membaca perubahan tingkat greyscale yang terdapat dipixel. Prinsip algoritma FCD ini yaitu saat bit berbeda pada lingkungan yang mempengaruhi cahaya [11].

Algoritma ini memiliki skema dengan menentukan titik sudut yang dianggap sebagai titik sudut $\mathrm{p}$, yang selanjutnya akan dilakukan input data 16 piksel disekeliling titik sudut $\mathrm{p}$.

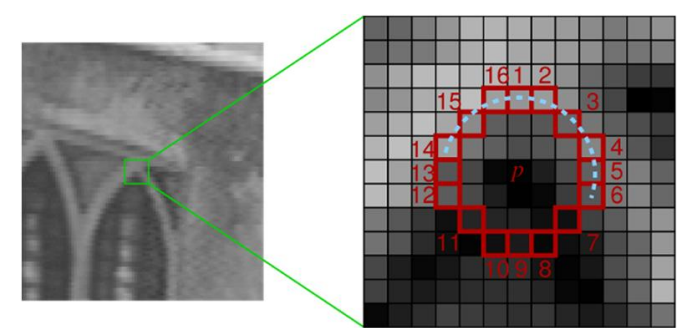

Gambar 1. FAST Corner Detection (sumber: Google)

Seperti yang terlihat pada gambar 1 merupakan proses pendeteksian titik sudut yang ada pada citra. Pendeteksian dipusatkan di titik $\mathrm{p}$ yang merupakan titik pusat dan menindentifikasi titik sekelilingnya.

Adam, et.,al, [Augmented Reality Pengenalan Landmark Negara Asia Tenggara Menggunakan Algoritma FAST Corner Dan Natural Feature Tracking] 


\subsection{Natural Feature Tracking}

Metode ini akan memperkirakan orientasi titik kunci dominan menggunakan gradien, lalu mengkompensasi orientasi yang terdeteksi, dan akhirnya menjelaskan titik kunci dalam hal gradient yang mengelilinginya. Natural Feature Tracking ini terdapat di library Vuforia [12]. NFT dimanfaatkan untuk menemukan poin - poin pola pada sebuah citra dan memastikan gambar dapat dikenali. Dengan NFT akan mempermudah dalam mendeteksi pola fitur.

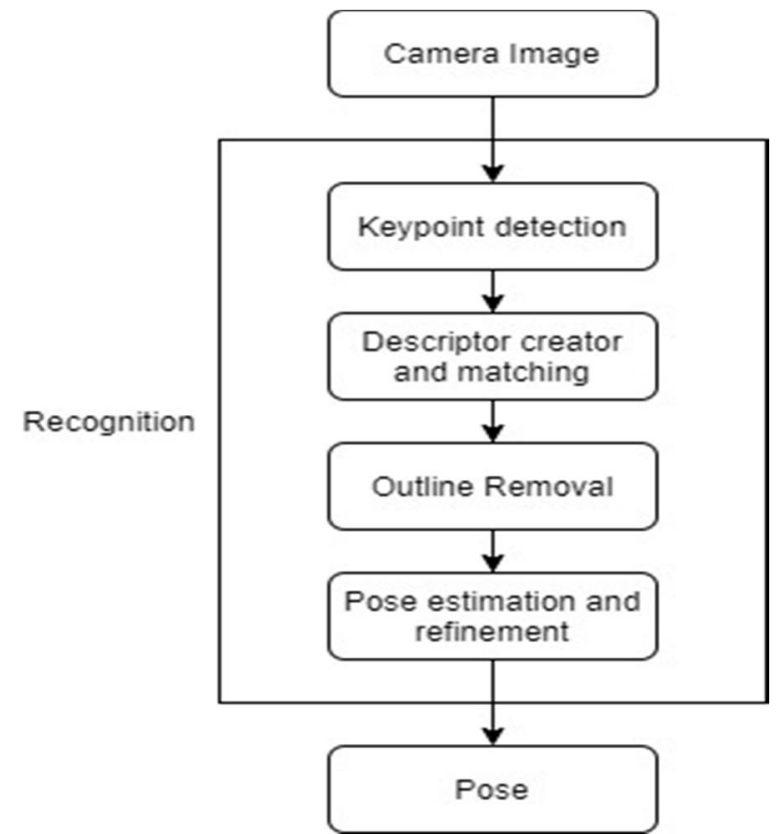

Gambar 2. Natural Feature Tracking

Pada gambar 2 menunjukan cara kerja dan tahapan NFT dalam proses pengenalan pola pola yang ada pada citra agar sebuah citra dapat diindentifikasi dengan baik.

\subsection{Flowchart Perancangan}

Flowchart merupakan penggambaran dari urutan perancangan aplikasi. Perancangan aplikasi di awali dengan tahap pengumpulan data, lalu mengidentifikasi masalah, kemudian dilakukan pembuatan objek 3D, selanjutnya pembuatan aplikasi, setelah itu dilakukan testing aplikasi apakah aplikasi dapat terbuka dan jalan dengan seharusnya atau belum, apabila terjadi error maka dilakukan testing ulang. Jika sudah berhasil maka aplikasi siap untuk digunakan. 


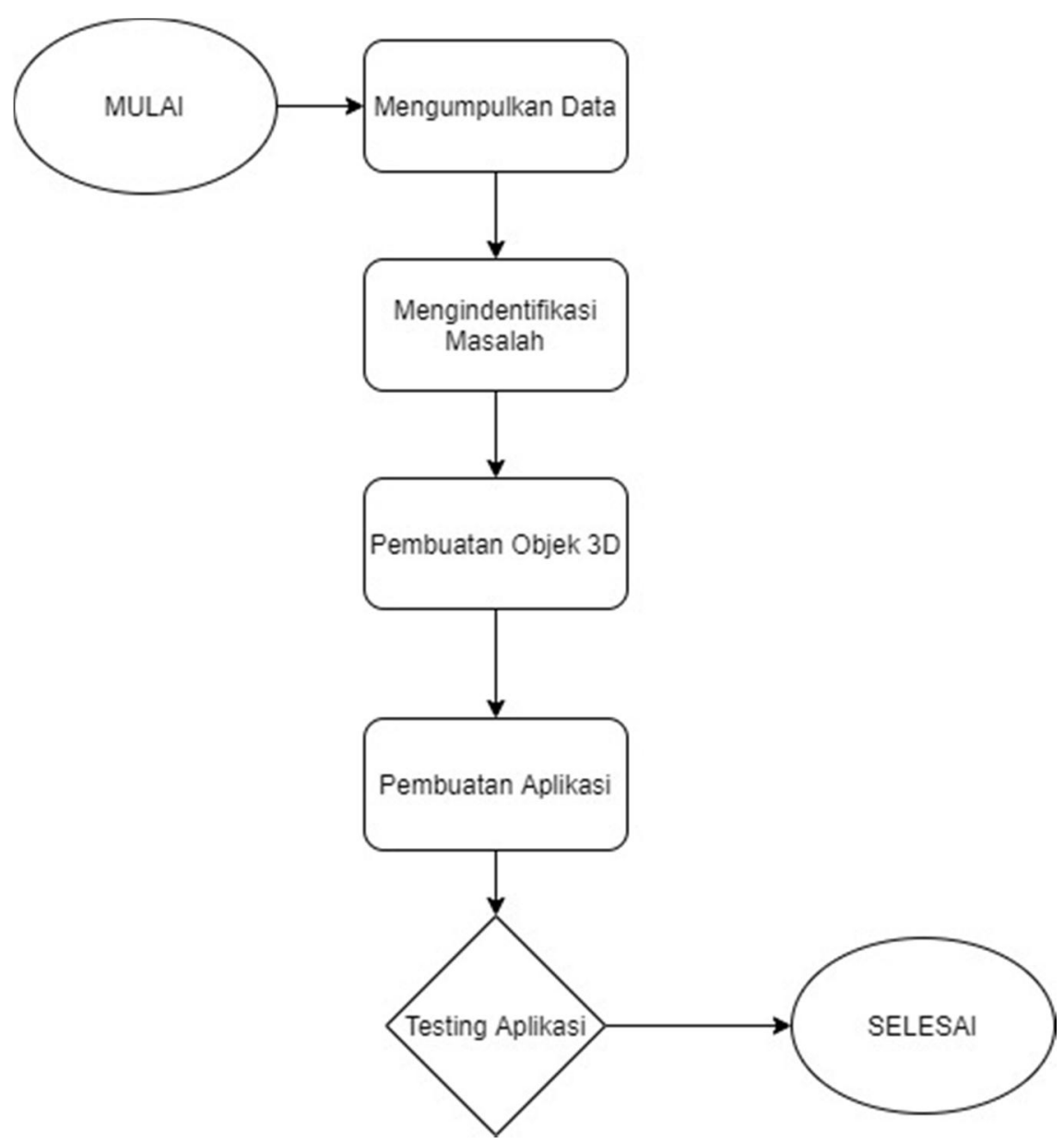

Gambar 3. Flowchart Perancangan Aplikasi

\subsection{Marker}

Marker merupakan sebuah media atau pola yang dibuat dalam bentuk sebuah gambar ataupun seperti QR code. Marker ini menjadi sebuah pola atau penanda yang ada di Augmented Reality dalam mendeteksi objek. Pembuatan marker dapat dilakukan dengan software figma atau adobe photoshop [13]. Setiap marker akan mempunyai pola - pola atau penanda yang berbeda. Dalam pendektesian marker pada Augmented Reality dibutuhkan kamera yang ada pada device smarphone pengguna untuk menampilkan objek 3 dimensi yang sesuai dengan marker. Marker memiliki peranan penting dalam kemunculan objek marker dan juga dapat dipengaruhi dari jarak penempatan marker. Pentingnya marker digunakan dalam augmented reality itu ditunjukan dari perannya yang sangat berguna untuk penempatan titik pada suatu objek yang dapat dikenali dengan bantuan sudut pencahayaan ruangan.

\subsection{Kebutuhan Sistem}

Dalam pembuatan aplikasi di penilitian ini peneliti membutuhkan alat - alat perangkat hardware serta perangkat software terkait dalam menunjang proses penyelesaian aplikasi, berikut alat-alatnya: 
Tabel 1. Kebutuhan Perangkat Hardware

\begin{tabular}{|c|c|}
\hline Perangkat & Kuantitas \\
\hline Prosesor & Intel i5 Generasi 8 \\
\hline RAM & 12GB \\
\hline Graphic Card & NVIDIA GeForce 930 MX \\
\hline HDD & $1 \mathrm{~TB}$ \\
\hline
\end{tabular}

Tabel 2. Kebutuhan Perangkat Software

\begin{tabular}{|c|}
\hline Software \\
\hline Unity 3D \\
\hline SketchUp \\
\hline Figma \\
\hline Adobe Photoshop \\
\hline
\end{tabular}

\section{HASIL DAN PEMBAHASAN}

\subsection{Flowchart Aplikasi}

Berikut merupakan penggambaran alur dari aplikasi pengenalan landmark negara asia tenggara menggunakan teknologi Augmented Reality.

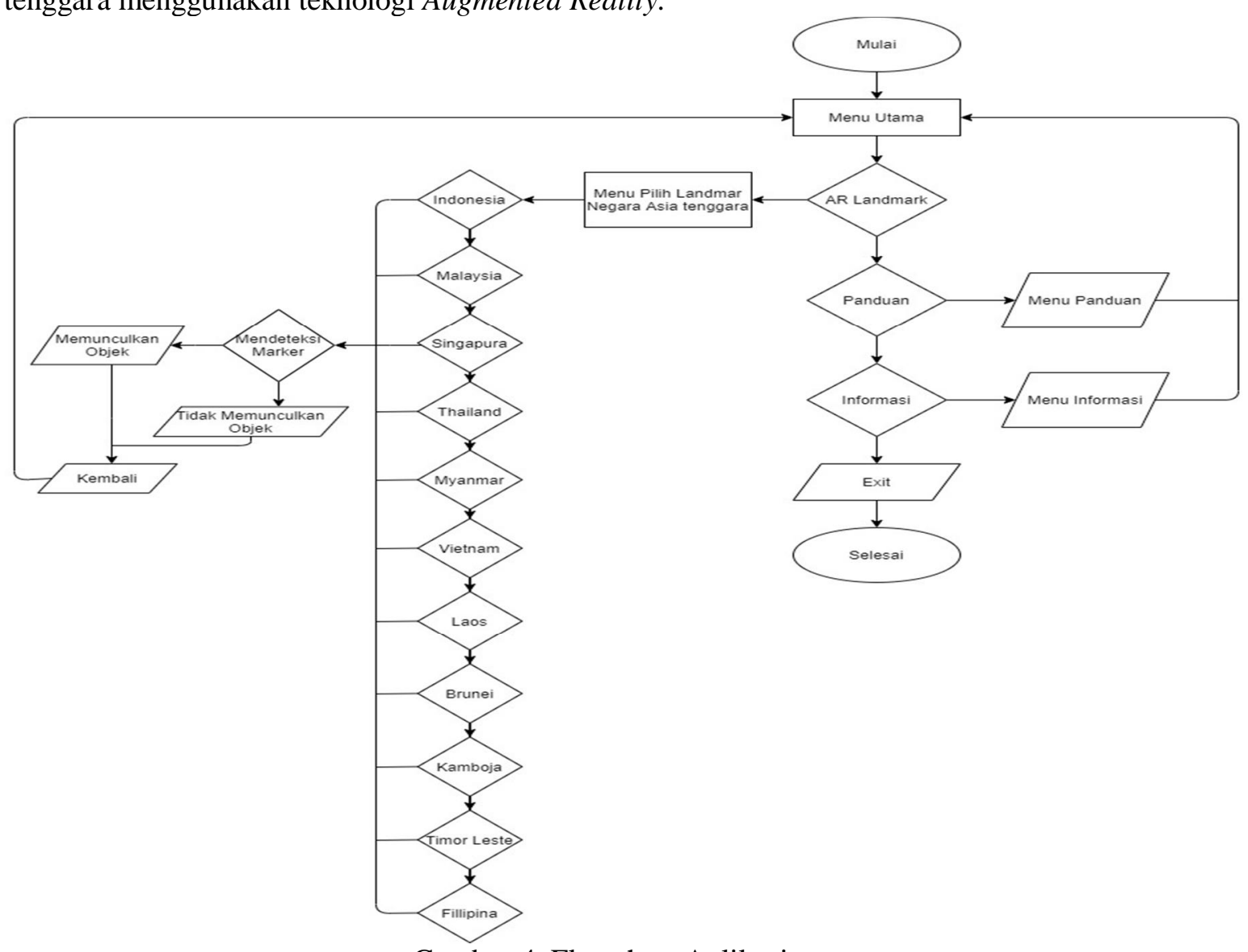

Gambar 4. Flowchart Aplikasi 
Sesuai dengan gambar 4 dijelaskan bagaimana cara alur kerja dari aplikasi pengenalan landmark negara asia tenggara dengan augmented reality. Alur pertama saat aplikasi dibuka akan langsung masuk ke bagian menu utama, pada bagian menu utama ini dapat memilih untuk ke menu AR Landmark, menu panduan, menu informasi. Jika memilih menu panduan akan di tampilkan cara menggunakan aplikasi dan tombol yang mengarahkan untuk mendownload marker, selanjutnya pada menu informasi akan menampilkan informasi aplikasi dan credit pembuat aplikasi. Saat memilih menu AR Landmark akan di beri pilihan negara - negara dari asia tenggara yang ingin ditampilkan bentuk landmarknya. Setelah memilih salah satu negara maka akan dilakukan pendeteksian marker jika terdeteksi akan muncul informasi tentang landmark tersebut dan menampilkannya dalam bentuk 3 dimensi, jika marker tidak terdeteksi maka tidak akan memunculkan objek 3 dimensinya. Dengan menekan tombol kembali maka akan dikembalikan ke bagian menu utama, selanjutnya dengan menekan tombol exit aplikasi ini akan otomatis tertutup.

\subsection{Penerapan FAST Corner Detection}

Pertama kali akan ditentukan dahulu koordinat titik utama $p$ yang berada di posisi utama $(x p, y p)$. Selanjutnya akan memilih empat titik koordinat, $(\mathrm{n}=1)$ yang terletak di titik $(\mathrm{xp}, \mathrm{yp}+3)$, $(n=2)$ yang terletak di titik $(x p+3, y p),(n=3)$ yang terletak di titik $(x p, y p-3),(n=4)$ terletak di titik (xp-3, yp). Selanjutnya akan memastikan 3 dari 4 titik koordinat telah memenuhi syarat.

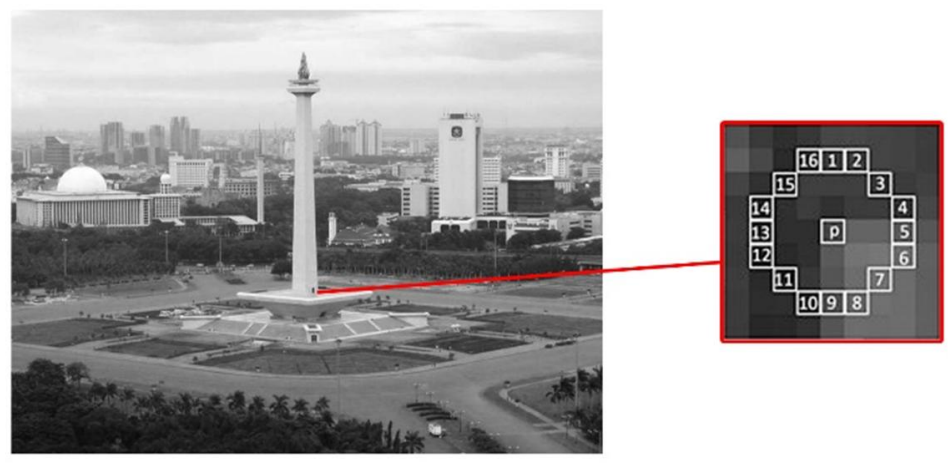

Gambar 5. Penerapan FAST Corner Detection

\subsection{Penerapan Natural Feature Tracking}

Dengan menggunakan NFT yang ada pada vuforia engine maka fitur natural yang terdapat pada marker akan ditampilkan dalam bentuk pola / symbol. Pola inilah yang nantinya akan dibaca untuk menampilkan objek 3D. Semakin banyak pola yang terbentuk semakin baik kamera dalam mengindentifikasi marker. 
Vol. 8, No. 3, September 2021, Hal. 1012-1026 E- ISSN 2503-2933 1019

Tabel 3. Penerapan Natural Feature Tracking

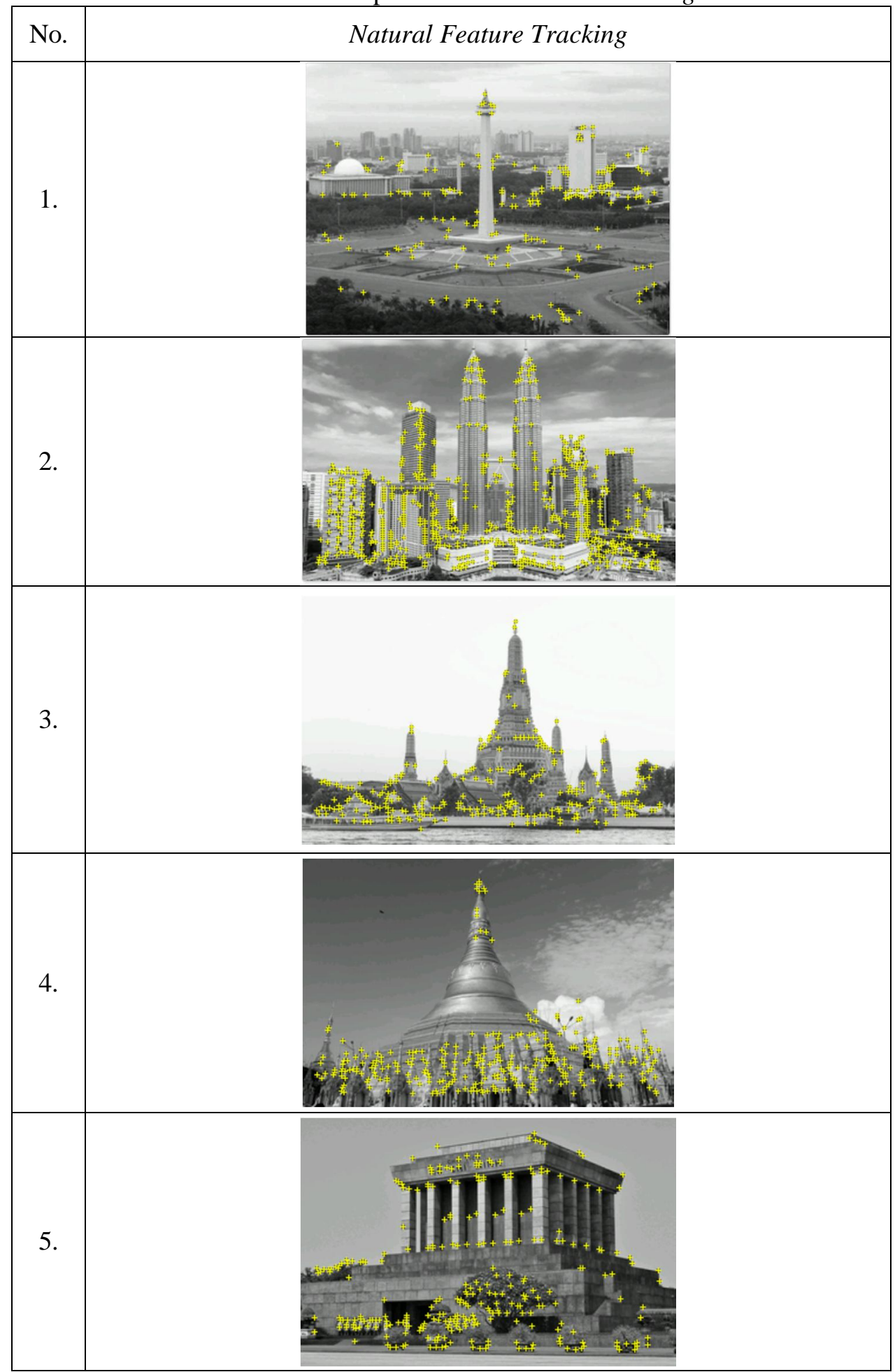


ISSN 2407-4322

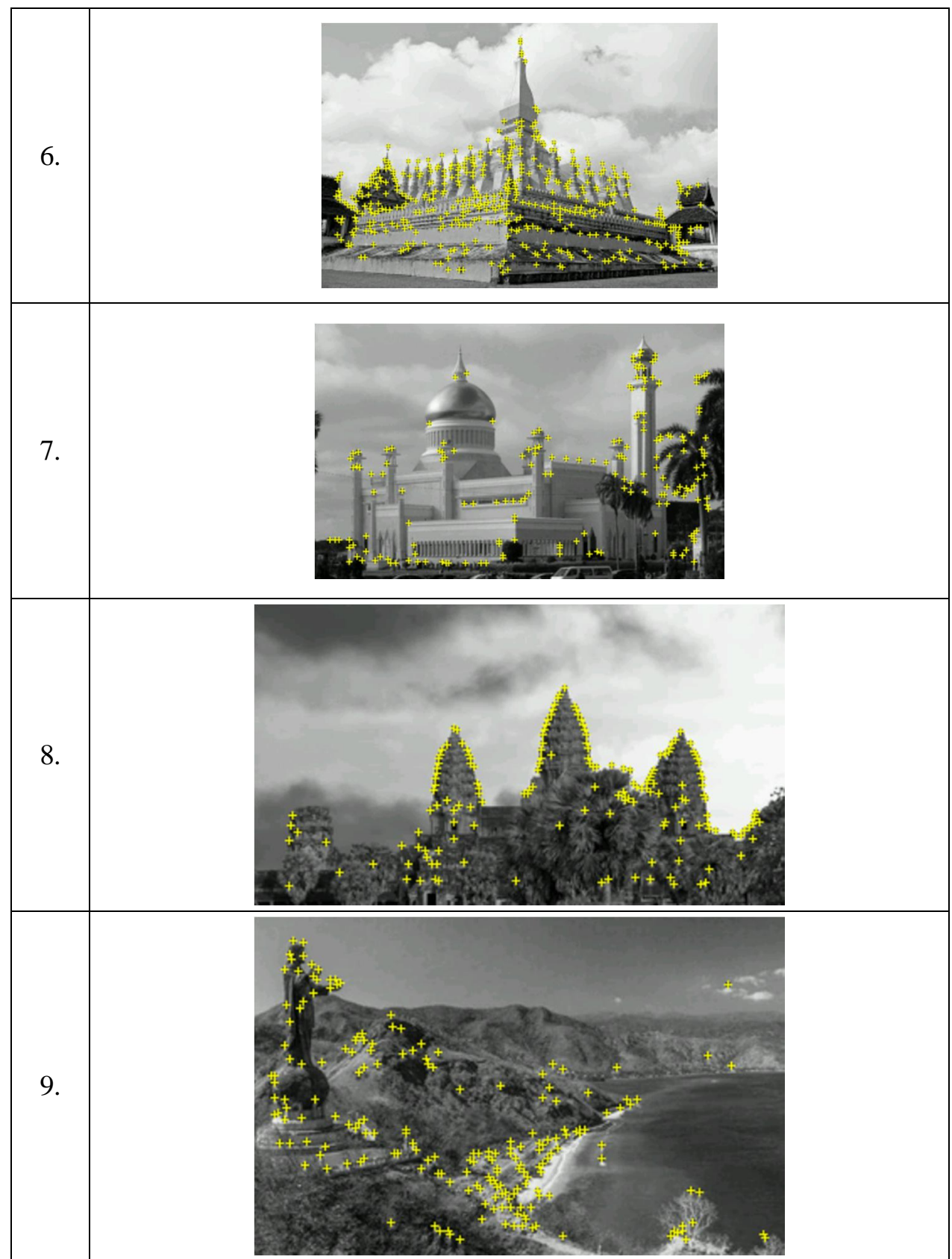




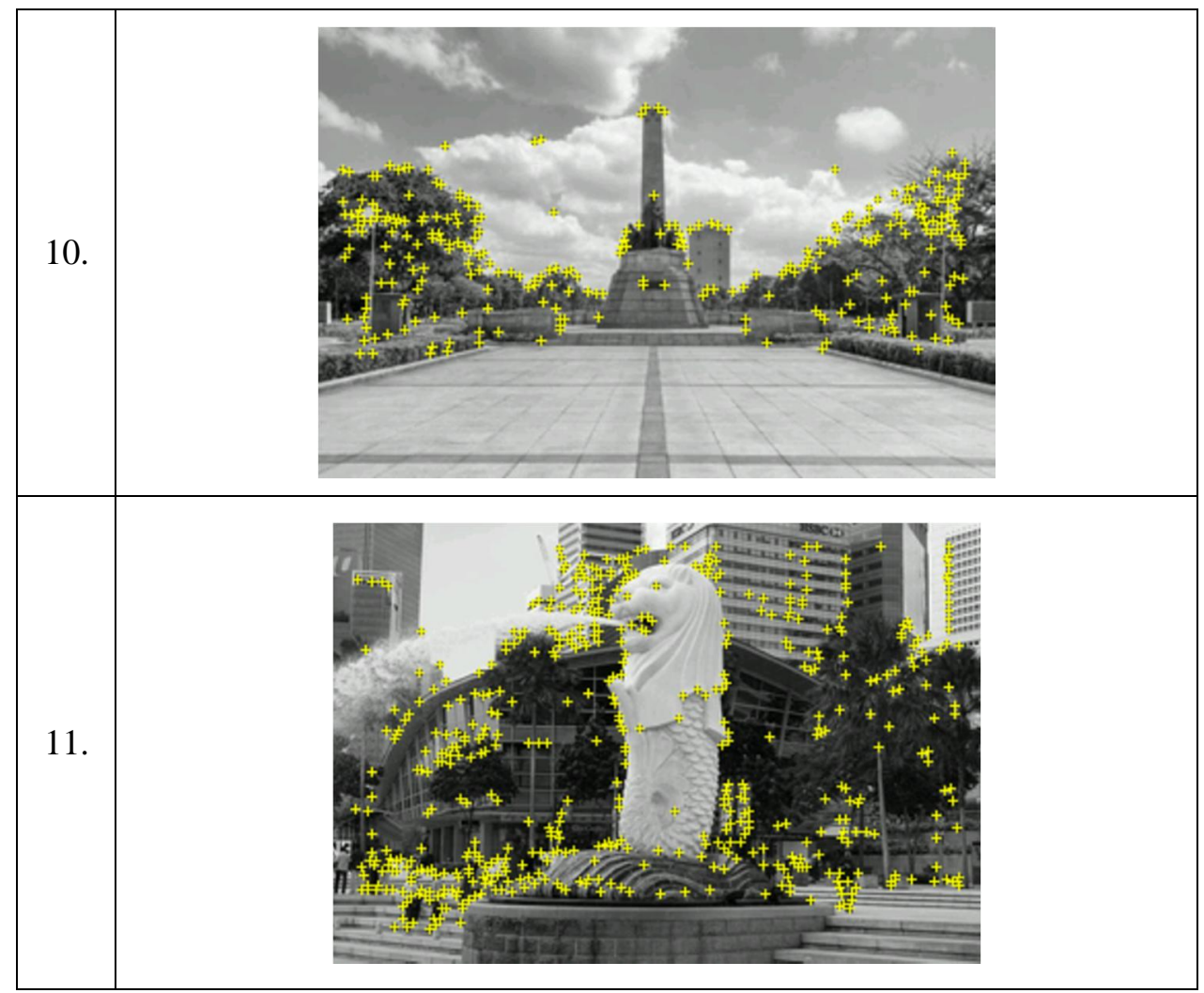

Pada tabel 3 menampilkan marker dari aplikasi pengenalan landmark negara Asia Tenggara (sumber: Google) yang sudah dilakukan penemuan pola - pola dengan metode NFT. Pola - pola yang diberikan akan berbeda untuk setiap gambar, karena gambar - gambar ini memiliki fitur yang berbeda dan memiliki bagian sudut - sudut yang berbeda.

\subsection{Penerapan Graphic User Interface}

Pada aplikasi diperlukan sebuah interface menarik agar tampilan dari aplikasi menjadi lebih menarik untuk digunakan oleh pengguna [14]. Aplikasi pada augmented reality pengenalan dari landmark negara asia tenggara ini menggunakan tampilan yang sederhana agar pengguna nyaman dan mudah menggunakan aplikasi ini. Berikut ini merupakan Graphical User Interface dari aplikasi:

Tabel 4. Hasil Tampilan User Interface

\begin{tabular}{|l|c|l|}
\hline No. & User Interface & \multicolumn{1}{|c|}{ Keterangan } \\
\hline & Asengenalan Landmark Negara Asia Tenggara \\
Augmented Reality & $\begin{array}{l}\text { Tampilan awal saat aplikasi } \\
\text { dibuka yaitu menu utama. } \\
\text { Pada menu utama terapat } \\
\text { empat pilihan tombol yang } \\
\text { dapat digunakan yaitu: AR } \\
\text { Landmark } \\
\text { Informasi dan Exit. Panduan, }\end{array}$ \\
\hline
\end{tabular}

Adam, et.,al, [Augmented Reality Pengenalan Landmark Negara Asia Tenggara Menggunakan Algoritma FAST Corner Dan Natural Feature Tracking] 


\begin{tabular}{|c|c|c|}
\hline 2. & 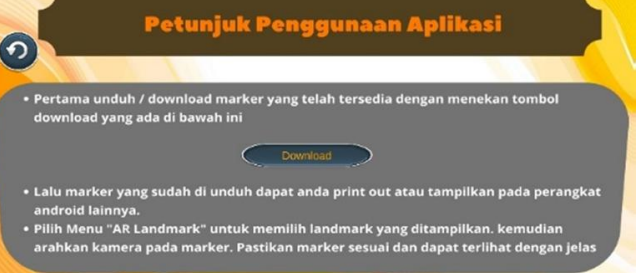 & $\begin{array}{l}\text { Pada menu panduan akan } \\
\text { ditampilkan informasi } \\
\text { bagaimana cara penggunaan } \\
\text { aplikasi dan juga ada tombol } \\
\text { download untuk mengunduh } \\
\text { marker yang tersedia }\end{array}$ \\
\hline 3. & $\begin{array}{l}\text { Aplikasi Pengenalan Landmark Negara Asia Tenggara dibuat } \\
\text { untuk memperkenalkan landmark yang ada di setiap negara Asia } \\
\text { Tenggara dalam bentuk Augmented Reality. } \\
\text { Aplikasi ini dibuat oleh: } \\
\text { Adam Raihan Fadhlurrahman } \\
\text { Universitas Nasional }\end{array}$ & $\begin{array}{l}\text { Bagian menu informasi } \\
\text { berisi tentang credit pembuat } \\
\text { aplikasi dan juga informasi } \\
\text { tentang aplikasi }\end{array}$ \\
\hline 4. & anno & $\begin{array}{l}\text { Menu AR Landmark } \\
\text { menampilkan negara - } \\
\text { negara dari asia tenggara } \\
\text { yang dapat dipilih untuk di } \\
\text { tampilkan landmark negara } \\
\text { tersebut }\end{array}$ \\
\hline 5. & 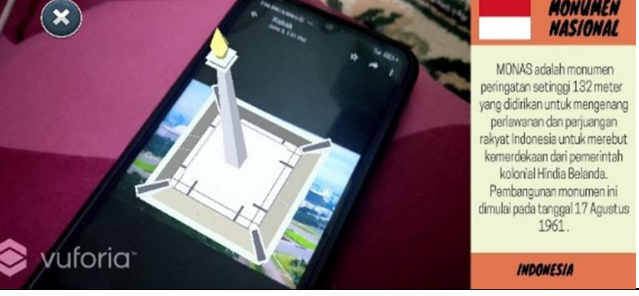 & $\begin{array}{l}\text { Menu Play ini akan } \\
\text { menampilkan objek 3D dari } \\
\text { negara yang telah di pilih } \\
\text { dan juga informasi tentang } \\
\text { landmark tersebut. }\end{array}$ \\
\hline
\end{tabular}

\subsection{Pengujian Aplikasi}

\subsubsection{Perangkat yang Dipakai}

Pada aplikasi ini dilakukan sejumlah pengujian aplikasi pada perangkat smartphone yang memiliki versi android berbeda - beda. Pengujian ini dilakukan agar mendapatkan hasil analisis terhadap smartphone yang berbeda.

Tabel 5. Perangkat yang Digunakan

\begin{tabular}{|l|l|}
\hline \multicolumn{1}{|c|}{ Perangkat } & \multicolumn{1}{c|}{ Model } \\
\hline Realme 3 Pro & Android 10.0 (Q) \\
\hline Xiaomi Redmi 8 & Android 9.0 (Pie) \\
\hline OPPO A37f & Android 5.1.1 (Lollipop) \\
\hline
\end{tabular}

Sesuai dengan tabel 5, dapat diketahui perangkat yang peneliti gunakan dalam melakukan pengujian aplikasi yaitu smartphone Realme 3 pro dengan versi android 10, Xiaomi Redmi 8 dengan versi android 9, dan OPPO A37f dengan versi android 5.1.1 . 


\subsubsection{Pengujian Jarak Maximal}

Tabel 6. Hasil dari Pengujian pada Jarak Maximal

\begin{tabular}{|l|l|l|}
\hline \multicolumn{1}{|c|}{ Perangkat } & \multicolumn{1}{c|}{ Model } & \multicolumn{1}{c|}{ Jarak Maximal } \\
\hline Realme 3 Pro & Android 10.0 (Q) & $\pm 80 \mathrm{~cm}$ \\
\hline Xiaomi Redmi 8 & Android 9.0 (Pie) & $\pm 75 \mathrm{~cm}$ \\
\hline OPPO A37f & Android 5.1.1 (Lollipop) & $\pm 70 \mathrm{~cm}$ \\
\hline
\end{tabular}

Setelah pengujian aplikasi dengan jarak maksimal pada tiga hanphone yang di uji dapat diketahui bahwa Realme 3 Pro dapat membaca dengan jarak maksimal $\pm 80 \mathrm{~cm}$, Xiaomi Redmi 8 dapat membaca dengan jarak maksimal $\pm 75 \mathrm{~cm}$, OPPO A37f dapat membaca dengan jarak maksimal $\pm 70 \mathrm{~cm}$. Jarak maksimal saat membaca marker dipengaruhi dengan kualitas kamera dari masing-masing smartphone.

\subsubsection{Pengujian Jarak Minimum}

Tabel 7. Hasil dari Pengujian Jarak Minimum

\begin{tabular}{|l|l|l|}
\hline \multicolumn{1}{|c|}{ Perangkat } & \multicolumn{1}{c|}{ Model } & \multicolumn{1}{c|}{ Jarak Minimum } \\
\hline Realme 3 Pro & Android 10.0 (Q) & $\pm 10 \mathrm{~cm}$ \\
\hline Xiaomi Redmi 8 & Android 9.0 (Pie) & $\pm 10 \mathrm{~cm}$ \\
\hline OPPO A37f & Android 5.1.1 (Lollipop) & $\pm 10 \mathrm{~cm}$ \\
\hline
\end{tabular}

Hasil dari pengujian pada jarak minimal pada tiga handphone diperoleh hasil pada jarak minimal $\pm 10 \mathrm{~cm}$ ketiga handphone tersebut dapat mendeteksi marker dan menampilkan objek landmark 3 dimensi dengan baik.

\subsubsection{Pengujian Pada Sudut Kemiringan}

Tabel 8. Pengujian pada Sudut Kemiringan

\begin{tabular}{|l|l|l|l|}
\hline \multicolumn{1}{|c|}{ Perangkat } & \multicolumn{1}{c|}{$<19^{\circ}$} & \multicolumn{1}{c|}{$20^{\circ}-59^{\circ}$} & \multicolumn{1}{c|}{$60^{\circ}-90^{\circ}$} \\
\hline Realme 3 Pro & Tidak dapat terdeteksi & Terdeteksi & Terdeteksi \\
\hline Xiaomi Redmi 8 & Tidak dapat terdeteksi & Terdeteksi & Terdeteksi \\
\hline OPPO A37f & Tidak dapat terdeteksi & Terdeteksi & Terdeteksi \\
\hline
\end{tabular}

Pada uji coba sudut kemiringan yang ada pada tabel 8 didapatkan hasil yang menunjukan pada sudut kemiringan $<19^{\circ}$ marker tidak dapat terdeteksi dan tidak berhasil menampilan objek 3 dimensi pada ketiga smartphone android tersebut. Pada sudut kemiringan $20^{\circ}-59^{\circ}$ marker dapat terdeteksi oleh smartphone android dan berhasil menampilkan objek 3 dimensi. Dan pada sudut kemiringan $60^{\circ}-90^{\circ}$ dapat terbaca dengan baik oleh perangkat android. 


\subsubsection{Pengujian Ketajaman Cahaya}

Tabel 9. Pengujian Ketajaman Cahaya

\begin{tabular}{|l|l|l|l|}
\hline \multicolumn{1}{|c|}{ Perangkat } & \multicolumn{1}{c|}{ Gelap } & \multicolumn{1}{c|}{ Remang } & \multicolumn{1}{c|}{ Terang } \\
\hline Realme 3 Pro & Tidak Terdeteksi & \pm 2 detik & \pm 1 detik \\
\hline Xiaomi Redmi 8 & Tidak Terdeteksi & \pm 2 detik & \pm 1 detik \\
\hline OPPO A37f & Tidak Terdeteksi & \pm 3 detik & \pm 1 detik \\
\hline
\end{tabular}

Pada tabel 9 merupakan hasil dari pengujian faktor cahaya terhadap ketiga perangkat smartphone android. Dalam keadaan cahaya yang gelap semua smartphone tidak dapat mendeteksi, pada saat keadaan cahaya remang dapat terdeteksi namun membutuhkan waktu yang lebih dalam pembacaannya, pada keadaan terang yang mempunyai banyak cahaya dapat mendeteksi dengan cepat.

\section{KESIMPULAN}

Kesimpulan dari hasil penelitian ini menciptakan sebuah aplikasi menggunakan teknologi Augmented Reality yang diciptakan untuk salah satu media pengenalan dari landmark negara asia tenggara. Aplikasi ini akan menampilkan objek 3 dimensi dan menampilkan informasi dari landmark tersebut. Aplikasi dalam penelitian ini memakai FAST Corner Detection algortima serta Natural Feature Tracking dalam pembacaan marker dan menapilkan objek 3 dimensi.

Dalam pengujian aplikasi terhadap ketiga hp didapatkan aplikasi dapat berjalan dengan lancar dan baik. Untuk pengujian jarak maksimal didapatkan hasil yang berbeda - beda, pada smartphone Realme 3 Pro didapatkan jarak maksimal yang dapat terbaca yaitu $\pm 80 \mathrm{~cm}$, pada smartphone Xiaomi Redmi 8 didapatkan jarak maksimal yang dapat terbaca yaitu $\pm 75 \mathrm{~cm}$, dan pada smartphone OPPO A37f didapatkan jarak maksimal yang dapat terbaca yaitu $\pm 70 \mathrm{~cm}$. Dalam pengujian minimum didapatkan hasil yang sama terhadap ketiga smartphone yaitu $\pm 10 \mathrm{~cm}$. Pada pengujian ketajaman cahaya dapat terlihat bahwa faktor cahaya sangat mempengaruhi dalam pendeteksian marker. Hasil yang diperoleh dari pengujian ini pada saat keadaan gelap tidak dapat membaca marker, namun saat ada cahaya aplikasi dapat mendeteksi marker.

\section{SARAN}

Untuk penelitian selanjutnya semoga dapat dilakukan penambahan objek dan menggunakan teknologi yang lebih canggih lagi seperti virtual rality dan lainnya. Dalam pembuatan objeknya dapat dibuat menjadi lebih bagus lagi dan penampilan UI yang lebih menarik.

\section{DAFTAR PUSTAKA}

[1] Edryanto, Irawan, and Effiyaldi, 2020. "Perancangan Aplikasi Augmented Reality Pengenalan Landmark Asia Tenggara Berbasis Android pada SDN 139/IV Jambi," J. Ilm. Mhs. Tek. Inform., Vol. 2, No. 1, pp. 31-42. 
[2] M. A. Barkah, 2018. "Pemanfaatan Augmented Reality (AR) Sebagai Media Pembelajaran Interaktif Pengenalan Candi-candi di Malang Raya Berbasis Mobile Android (Doctoral Dissertation. Universitas Kanjuruhan Malang.," pp. 1-6.

[3] M. S. Okriyanto, A. Erlansari, and Ernawati, 2018. "Aplikasi Ar-Hb (Augmented Reality and Historical Building) Sebagai Media Promosi dan Pengenalan Bangunan Bersejarah Dikota Bengkulu,” J. Rekursif, Vol. 6, No. 2, pp. 13-21.

[4] F. Haris and O. D. Hendrati 2018, "Pemanfaatan Augmented Reality Untuk Pengenalan Landmark Pariwisata Kota Surakarta,” J. Teknoinfo, Vol. 12, No. 1, p. 7, doi: 10.33365/jti.v12i1.41.

[5] S. Nazilah and F. S. Ramdhan, 2021. "Augmented Reality Sebagai Media Pembelajaran Untuk Pengenalan Landmark Negara-Negara ASEAN Berbasis Android Dengan Menggunakan Metode Marker Based Tracking,” Vol. 5, No. 2, pp. 99-107.

[6] P. A. Sudyatmika, P. N. Crisnapati, I. G. M. Darmawiguna, and M. W. Antara Kesiman, 2014, "Pengembangan Aplikasi Augmented Reality Book Pengenalan Objek Wisata Taman Ujung Soekasada dan Taman Ar Tirta Gangga di Kabupaten Karangasem," J. Pendidik. Teknol. dan Kejuru., Vol. 11, No. 2, doi: 10.23887/jptk.v11i2.4083.

[7] I. Bagus and M. Mahendra, 2016. "Implementasi Augmented Reality (Ar) Menggunakan Unity 3D dan Vuporia Sdk, ” J. Ilm. ILMU Komput. Univ. Udayana, Vol. 9, No. 1, pp. 15.

[8] T. O. Purba, H. Mukhtar, and Y. Fatma, 2019, "Pengenalan Monumen-Monumen Bersejarah di Kota Pekanbaru Menggunakan Augmented Reality (AR) Berbasis Android," Proseding SemNas CTiA, Vol. 1, No. 1, pp. 1-4.

[9] J. Llerena, M. Andina, and J. Grijalva, 2018. "Mobile Application to Promote The Malecón 2000 Tourism Using Augmented Reality and Geolocation,” Proc. - 3rd Int. Conf. Inf. Syst. Comput. Sci. INCISCOS 2018, Vol. 2018-Decem, pp. 213-220.

[10] A. Willis and Y. Sui, 2009, “An Algebraic Model For Fast Corner Detection," Proc. IEEE Int. Conf. Comput. Vis., No. Iccv, pp. 2296-2302, doi: 10.1109/ICCV.2009.5459443.

[11] H. Zhang, L. Xiao, and G. Xu, 2020, "A Novel Tracking Method Based on Improved FAST Corner Detection and Pyramid LK Optical Flow," Proc. 32nd Chinese Control Decis. Conf. CCDC 2020, pp. 1871-1876, doi: 10.1109/CCDC49329.2020.9164332.

[12] I. S. Wijaya, 2017, “Rancangan Prototype Aplikasi Teknologi Augmented Reality (AR) Pengenalan Monumen Bersejarah di Kota Jambi Dengan Menggunakan Patern Recognition Metode Natural Feature Tracking (NFT) Secara Real Time," Semin. Nas. Teknol. Inf., pp. 1-5.

[13] R. Atikah Khansa, 2017, “The Pengembangan Aplikasi 'Indonesian Landmark' Berbasis Android Dengan Teknologi Augmented Reality," KOPERTIP J. Ilm. Manaj. Inform. dan Komput., Vol. 1, No. 2, pp. 77-84, doi: 10.32485/kopertip.v1i02.12. 
[14] G. Y. Abdillah, S. Andryana, and A. Iskandar, 2020. “Augmented Reality Sebagai Media Pembelajaran Perangkat Keras Komputer Dengan Fast Corner dan Natural Feature Tracking," JIPI (Jurnal Ilm. Penelit. dan Pembelajaran Inform., Vol. 5, No. 2, p. 79, 